\title{
CKS1 expression in melanocytic nevi and melanoma
}

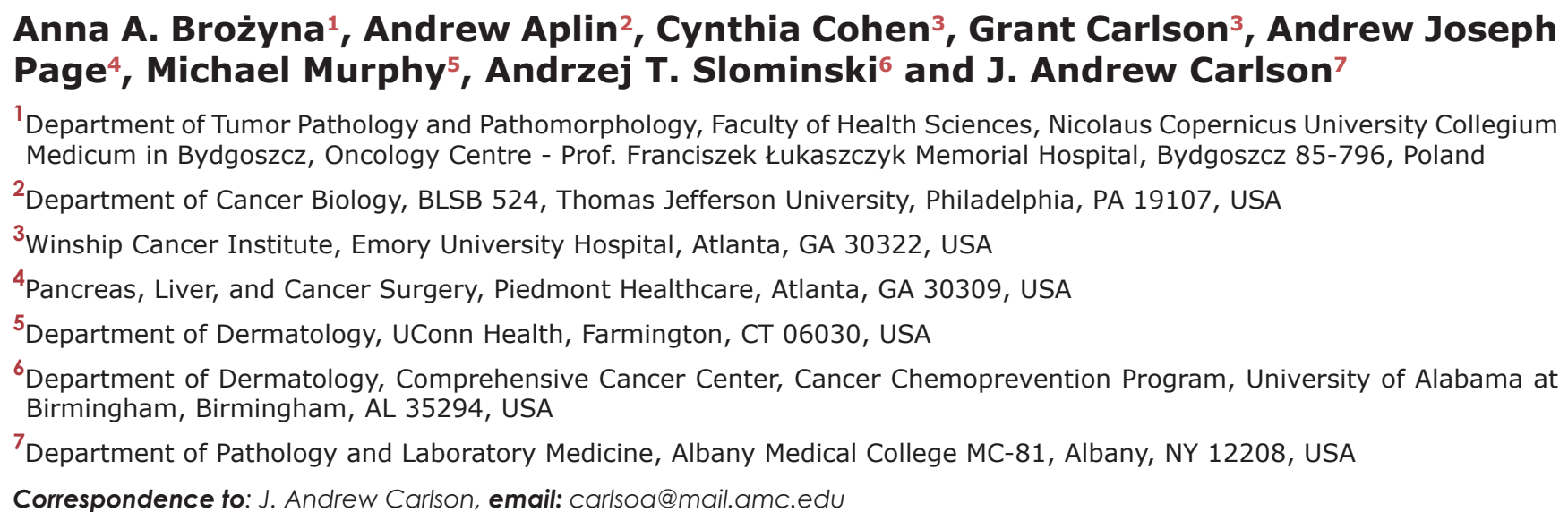
Keywords: melanoma; Skp2; ubiquitination; p27; prognosis

Received: November 07, $2017 \quad$ Accepted: December 16, $2017 \quad$ Published: December 23, 2017

Copyright: Brożyna et al. This is an open-access article distributed under the terms of the Creative Commons Attribution License 3.0 (CC BY 3.0), which permits unrestricted use, distribution, and reproduction in any medium, provided the original author and source are credited.

\section{ABSTRACT}

Cyclin-dependent kinase subunit 1 (Cks1) regulates the degradation of p27, an important G1-S inhibitor, which is up regulated by MAPK pathway activation. In this study, we sought to determine whether Cks1 expression is increased in melanocytic tumors and correlates with outcome and/or other clinicopathologic prognostic markers. Cks1 expression was assessed by immunohistochemistry in 298 melanocytic lesions. The frequency and intensity of cytoplasmic and nuclear expression was scored as a labeling index and correlated with clinico-pathological data. Nuclear Cks1 protein was found in $63 \%$ of melanocytic nevi, $89 \%$ primary and $90 \%$ metastatic melanomas with mean labeling index of $7 \pm 16,19 \pm 20$, and $30 \pm$ 29, respectively. While cytoplasmic Cks1 was found in $41 \%$ of melanocytic nevi, $84 \%$ primary and $95 \%$ metastatic melanomas with mean labeling index of $18 \pm 34,35 \pm$ 34, and $52 \pm 34$, accordingly. Histologic stepwise model of tumor progression, defined as progression from benign nevi to primary melanomas, to melanoma metastases, revealed a significant increase in nuclear and cytoplasmic Cks1 expression with tumor progression. Nuclear and cytoplasmic Cks1 expression correlated with the presence of ulceration, increased mitotic rate, Breslow depth, Clark level, tumor infiltrating lymphocytes and gender. However, other well-known prognostic factors (age, anatomic site, and regression) did not correlate with any type of Cks1 expression. Similarly, increasing nuclear expression of Cks1 significantly correlated with worse overall survival. Thus, Cks1 expression appears to play a role in the progression of melanoma, where high levels of expression are associated with poor outcome. Cytoplasmic expression of Cks1 might represent high turnover of protein via the ubiquination/proteosome pathway. 


\section{INTRODUCTION}

Cell cycle deregulation is a cornerstone of malignant transformation, leading to increased proliferation and growth rates. It is widely accepted that cell-cycle destabilization is common to many human malignancies. Induction of cellular proliferation is carried out in large part at the transcriptional level, where cis- and transactivating factors induce the transcription of cell cycle progression mediators. Furthermore, ubiquitin ligasemediated degradation of cell cycle progression factors represents a further level of regulation. It is this tight regulation of cell-cycle progression, which maintains tissue homeostasis. In normal tissue, cyclin-dependent kinase (CDK) activity is inhibited in the absence of mitogens, by the protein $\mathrm{p} 27$, via the ubiquitin proteasome pathway [1] (Figure 1).

The cyclin-dependent kinase subunit family is a highly phylogenetically conserved family of small (9$18 \mathrm{kDa}$ ) proteins. There are two distinct orthologues, Cks 1 and Cks2 in vertebrates [2,3]. Cks1 is required in $\mathrm{SCF}^{\text {skp2 }}$ driven p27 ubiquitinylation [2]. Cks1 induces an allosteric change in the Skp2 component of $\mathrm{SCF}^{\mathrm{skp} 2}$ ubiquitin ligase, allowing it to bind phosphorylated p27. This in turn allows for efficient transfer of the ubiquitin moiety, which, once bound to $\mathrm{p} 27$, leads to subsequent recognition by the proteasome $[1,4]$. Cells lacking p27 degradation can progress abnormally through the cell cycle, because of unopposed CDK activity.

A likely mechanism for overexpression of Cks1, observed in many human malignancies [5-13], is cisactivation of the Cks1 gene promoter by proto-oncogenes such as Myc. Myc normally accelerates cell-cycle progression and its overexpression has been implicated in many tumors such as Burkitt's lymphoma. Interestingly, quantitative mRNA expression analysis in Burkitt's lymphoma-derived B-cells reveals increased Cks1 transcript levels, which suggests myc-dependent Cks1 overexpression and in turn increased p27 turnover, thereby allowing the malignant B-cells to transit through the cell cycle [14]. Cks1 also activates the transcription of factors responsible for cell-cycle progression and is associated with increased proliferation in several cell types [15].

Melanoma arises from malignant transformation of melanocytes and is one of the deadliest forms of skin cancer [5]. Melanocytes rely on adhesion factors to activate

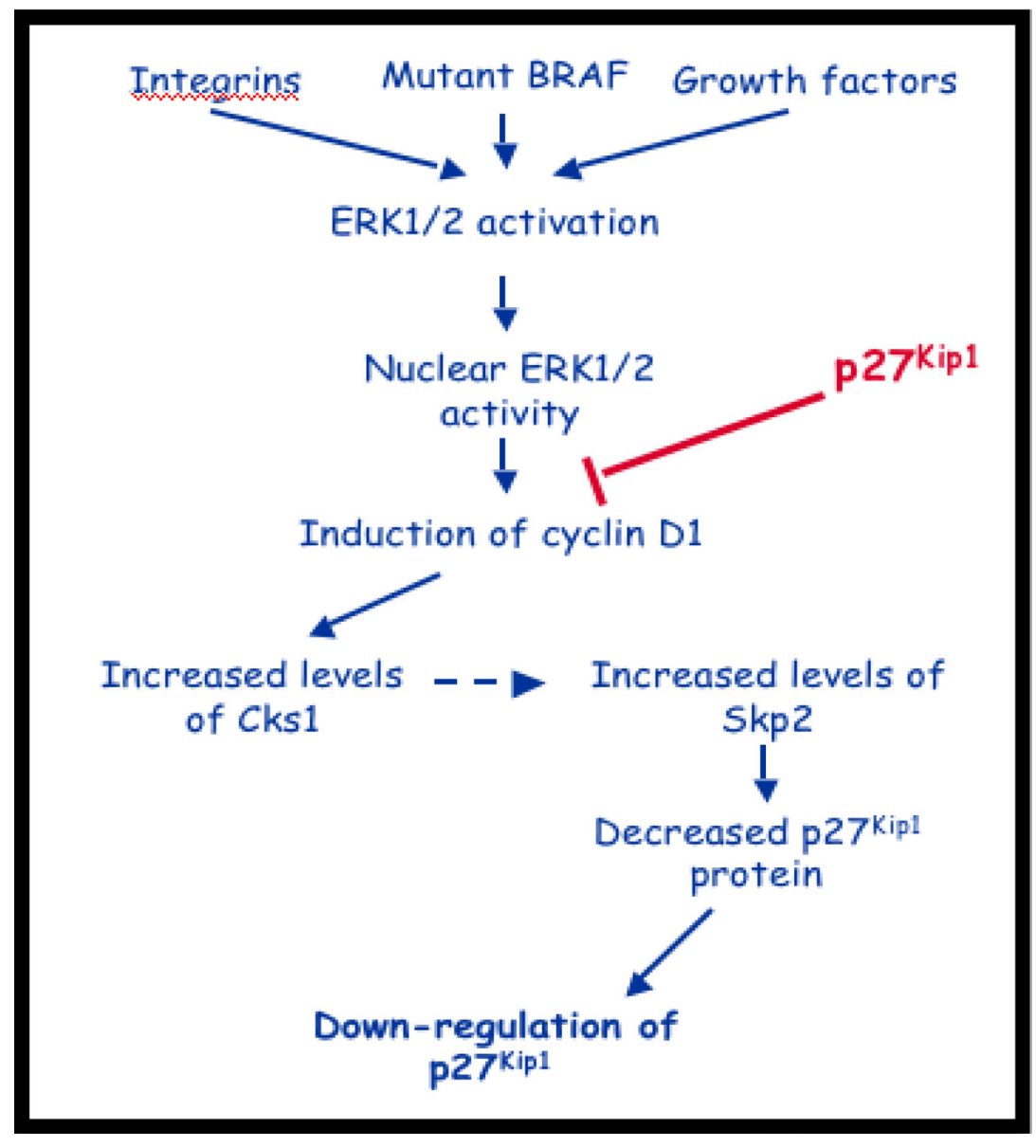

Figure 1: Putative role of Cks1 in pathogenesis of melanoma. Constitutive activation of the MAPK pathway leads to increased Cks1 expression and down regulation of $\mathrm{p} 27$, a crucial G1-S cell-cycle regulator. 
extracellular signal-regulated kinase 1/2 (ERK1/2), which, in turn induces cyclin D1 and down regulates p27 [16]. B-RAF regulates p27 mRNA abundance, independently of cyclin D1, and mutations of B-RAF are implicated in $70 \%$ of melanomas [17]. B-RAF controls p27 expression in melanoma cells at the mRNA level and at the level of proteasome degradation. The latter is cyclin D1-dependent and occurs via regulation of Cks1 and Skp2 [6]. B-RAF knockout mice showed decreased levels of cyclin D1 and increased levels of p27. Mice lacking Cks1 had lower Skp2 levels and an increase in p27 levels. Mice lacking both Cks1 and Skp2 harbored a further increase in p27 levels compared to Skp2 knockouts alone. Individual knockouts of either Cks1 or Skp2 significantly reduced cell growth [5]. This appears to support the hypothesis that B-RAF and cyclin D1 control expression of Cks1 and Skp2, which, in turn, mediate degradation of p27 in melanoma cells.

The most common mutation of B-RAF, V600E, hyper-activates B-RAF and the downstream mitogenactivated protein kinase (MEK)-ERK1/2 pathway. This pathway is an important regulator of G1-S progression. Indeed, several studies have shown that B-RAF ${ }^{\mathrm{V} 600 \mathrm{E}}-\mathrm{MEK}$ signaling is necessary for melanoma cell $\mathrm{S}$ phase entry, proliferation and anchorage-independent growth in vitro [18-22] and for melanoma cell sub-cutaneous growth in nude mice $[21,23]$. Underscoring the importance of RAF-MEK-ERK1/2 signaling, this pathway may also be hyper-activated in melanomas expressing wild-type B-RAF through mutation of RAS, aberrant expression of G-protein coupled receptors and/or up-regulation of autocrine growth factors $[24,25]$. It is critical to identify cell cycle markers that correlate with increased B-RAF signaling in melanoma since they may serve as tumor biomarkers, and alterations in their expression/regulation may underlie de novo or secondary resistance to B-RAF and MEK inhibitors.

Skp1-cullin1-F-box (SCF) E3 ubiquitin ligase complexes have been identified as important regulators of cell cycle progression $[26,27]$ as aberrant expression of Skp2 is an adverse prognostic sign in melanoma [28]. The F-box protein determines the substrate specificity of the complex. Skp2 is the F-box protein involved in SCFmediated degradation of the cyclin-dependent kinase inhibitor, p27, during late G1 and S phase [4, 29-31]. Skp2 also targets p57, p21, cyclin E1 and origin recognition complex 1 (Orc1) for degradation [4, 30, 32-34]. Skp2 is required for melanoma cell growth, however in a manner independent of p27 but dependent on p53 [35]. In addition to SCF components, Skp2 requires a cofactor, cdc kinase subunit 1 (Cks1) [2, 4]. Recently demonstrated, mutant B-RAF-MEK signaling regulates Cks1 expression in melanoma cells [5]. Furthermore, Cks1 was found to regulate $\mathrm{Skp} 2$ expression and that $\mathrm{Cks} 1 / \mathrm{Skp} 2$ complexes mediate B-RAF effects on p27 $7^{\mathrm{Kip} 1}$ [5]. Importantly, earlier work on correlations between the pathological and immunohistochemical profiles in melanomas found that Skp2 cytoplasmic levels correlated with aggressive melanomas and predicted poorer 10-year survival rate [28].

Given the previously suspected role of $\mathrm{Cks} 1$ in regulating Skp2 [22, 28], herein, we investigated Cks1 Expression in a number of different melanocytic lesions, from common melanocytic nevi to metastatic melanoma to assess its role in melanoma progression and its impact on prognosis in primary melanoma patients.

\section{RESULTS}

\section{Normal skin Cks1 expression}

In control lymph nodes, lymphocytes within germinal follicles strongly expressed nuclear Cks1. Cks1 expression was assessed in the skin adjacent to melanocytic lesions (Figure 2). Table 1 summarizes these observations. Normal (resting) and hyperplastic epidermis (psoriasiform hyperplasia of epidermis adjacent to ulcers, overlying scars, or in regions of lichenification, eccrine coils, and follicular bulbs all showed strong, widespread nuclear Cks1 expression. However, only hyperplastic, not 'resting' keratinocytes exhibited cytoplasmic Cks1 expression. Sebocytes, follicular keratinocytes and smooth muscle cells of pilar erectus and media of vessels also expressed cytoplasmic Cks1. No Cks1 expression was seen in normal, junctional melanocytes.

\section{Melanocyte phenotype and Cks1 expression}

Cks1 was found in melanocytic lesions and its expression was diverse by melanocytic nevus or melanoma cell cytologic phenotypes, or by pattern of growth. Uncommon nevi and dysplastic nevi showed some nuclear staining. Most melanocytic lesions, however, showed cytoplasmic staining. All melanoma showed variable nuclear staining (Figure 3).

\section{Quantification of Cks1 expression in melanocytic nevi, melanoma, and metastases}

Table 2 summarizes the results for Cks1 overall expression and labeling indices for all melanocytic lesions by histologic classification (Figure 3,4). Analysis of 123 primary melanomas with both in situ and invasive components revealed similar Cks1 expression in both components in 65 cases, higher Cks1 expression of in situ component in 38 cases and higher Cks1 expression in invasive component in 20 cases. Comparison of different histological subtypes of melanomas revealed highest Cks1 labeling index, especially nuclear staining, in nodular, desmoplastic and mucosal melanomas, indicating its correlation with aggressive histopathologic subtypes (Figure 5). Notably, expression of cytoplasmic Cks1 was 
significantly higher in primary melanomas from patients with a positive sentinel lymph node metastasis compared to primary melanomas from patients with a negative sentinel lymph node biopsy $(55.7 \pm 33.4$ versus $36.6 \pm$ 34.6, respectively, $p=0.01$ for cytoplasmic Cks1 labeling index). However, no differences were noted for nuclear Cks1 labeling index in primary melanomas with or without an associated sentinel lymph node metastasis $(19.6 \pm 18.7$ versus $23.8 \pm 21.2$, respectively, $p=0.21$ ). Matched analysis of Cks1 expression in primary and metastatic melanomas from the same patients $(n=22)$ showed higher nuclear Cks1 labeling index in metastatic lesions in 13 cases, lower in 6 cases and similar expression in 4 cases $(n=23$; in analyzed cohort one patient had two metastatic lesions evaluated by immunohistochemistry). Higher cytoplasmic Cks1 expression in metastatic melanomas was found in 13, lower in 9 and comparableCks1 expression in 1 patient.

\section{Cks1 expression and melanoma progression}

By linear regression methods, both nuclear and cytoplasmic Cks1 correlated with stepwise progression from melanocytic nevi to melanomas in situ, to primary melanomas, to metastatic melanomas $(r=0.34, p<0.0001$ and $r=0.32, p<0.0001$, respectively). With increasing American Joint Commission on Cancer (AJCC) tumor classification, nuclear and cytoplasmic Cks1 showed also significant positive correlation $(r=0.26, p=0.0003$, and $r=0.26, p<0.0001$, respectively). By AJCC stage (Ia, Ib, IIa, IIb, IIc, III (lymph node metastatic melanomas), and IV (visceral and distant skin metastatic melanomas)), nuclear and cytoplasmic Cks1 correlated with increasing AJCC stage $(r=0.22, p=0.0024$, and $r=0.36, p<$ 0.0001 , respectively). See Table 3 for direct comparison of Cks1 expression with standard clinical and histologic prognostic markers.

\section{Comparison of Cks1 labeling index with histologic prognostic biomarkers}

Both nuclear and cytoplasmic, Cks1 expression positively correlated with well-known prognostic factors (Tables 3 and 4). Specifically, the presence of ulceration $(r=0.21, p=0.004$ and $r=0.31, p<0.0001$,

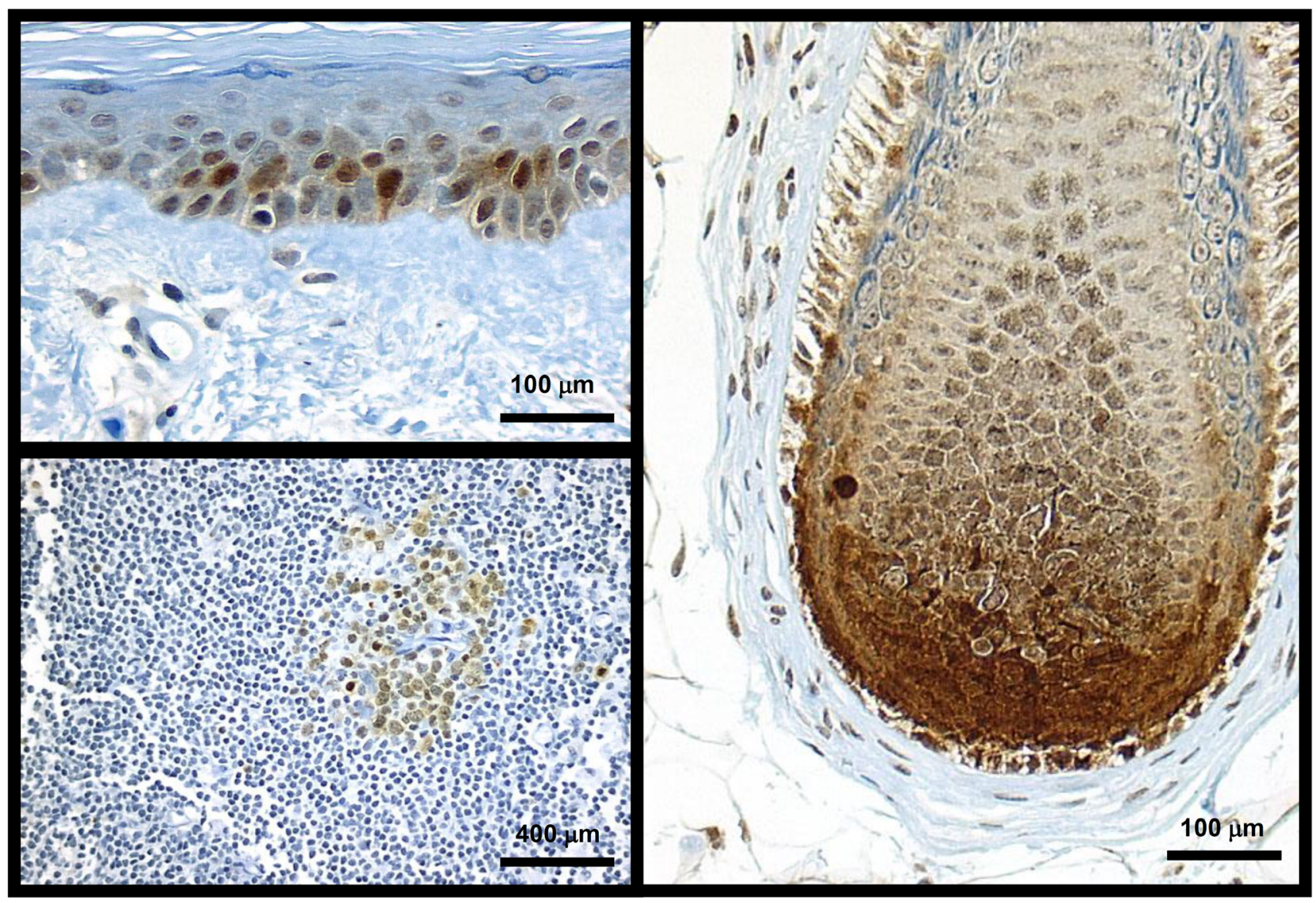

Figure 2: Cks1 expression in normal skin and lymph node was seen only in proliferating cells. Sun-damaged skin with scattered keratinocytes showing Cks1 nuclear and cytoplasmic expression; normal melanocytes did not express Cks1 (top left). Follicular anagen bulb's matrical keratinocytes exhibited intense nuclear and cytoplasmic expression of Cks1. Intervening dendritic melanocytes show faint nuclear and cytoplasmic Cks1 expression (right panel). Follicle center cells (bottom left) from a lymph node show low level of cytoplasmic and nuclear expression. 
Table 1: Cks1 expression in normal skin and lymphoid follicles

\begin{tabular}{lcc}
\hline Normal skin constituents & Nuclear Cks1 & Cytoplasmic Cks1 \\
\hline Adipocytes & + & + \\
Dermal scar/fibrosis & + & $+/-$ \\
Eccrine ducts and coils & + & - \\
Epidermis, normal & + & +- \\
$\quad$ Solar elastosis present & ++ & +- \\
$\quad$ Hyperplastic epidermis & + & $+/-$ \\
Follicular bulbar keratinocytes & ++ & ++ \\
Lymphoid follicles & - & - \\
Melanocytes & - & + \\
Nerves & - & + \\
Sebocytes & +- & + \\
Smooth muscle cells & +- & - \\
\hline
\end{tabular}

-:no expression; +/-:weak and variable expression; +:expression: ++: strong expression.

respectively), increasing mitotic rate $(r=0.33, p<0.0001$ and $r=0.27, p=0.0002$, respectively), tumor thickness $(r$ $=0.2, p=0.006$, and $r=0.35, p<0.0001$, respectively), Clark level $(r=0.18, p=0.011$ and $r=0.17, p=0.016$, respectively). In addition, Cks1 expression negatively correlated with tumor infiltrating lymphocytes (for nuclear Cks1 labeling index $r=-0.25, p=0.0007$, and for cytoplasmic Cks1 labeling index $r=-0.18, p=0.011)$. Cks1 nuclear labeling index correlated also with sex $(r$ $=0.15, p=0.028)$. However, other prognostic factors (age, anatomic site, vascular invasion and regression) did not correlate with nuclear or cytoplasmic Cks1 expression. There was no correlation between melanin pigmentation and $\mathrm{Cks} 1$ expression in radial growth phase. However, melanin content negatively correlated with nuclear Cks1 expression in vertical growth phase (Table 4). Furthermore, positive correlation between melanin pigmentation and both cytoplasmic and nuclear Cks1 expression in metastases was found (Table 4). Other relevant correlations of $\mathrm{Cks} 1$ expression with histopathological characteristics are presented in Table 4.

\section{Survival analysis and Cks1 expression}

By univariate analysis, nuclear and cytoplasmic Cks1 labeling index $(\geq 20)$ was found to be a predictor of poor disease-free and overall survival (Table 5, Figure 6). We also found that AJCC stage, depth, Clark's level, ulceration, TILs, mitosis, vascularity and angioinvasion were predictors of disease-free survival and overall survival (Table 5). However, Cks1 expression was not an independent prognostic factor of disease-free survival and overall survival in melanoma patients on multivariate analysis. By multivariate analysis, age (Hazard ratio (HR) $=1.04 ; p=0.001)$, vascular invasion $(\mathrm{HR}=4.78 ; p=$ $0.0001)$ and AJCC stage $(\mathrm{HR}=2.1 ; p=0.003)$ were found to be independent overall survival factors.

\section{DISCUSSION}

In this study, we found a significant increase in nuclear and cytoplasmic Cks1 expression with melanocytic tumor progression from melanocytic nevi to primary melanomas to metastatic melanomas. The results showed that overexpression of Cks1 in primary melanomas positively correlated with tumor advancement (Breslow thickness, Clark level, AJCC stage) and other well-known prognostic factors, such as gender, ulceration, mitotic counts, and negatively correlated with the presence of tumor infiltrating lymphocytes. In addition to nuclear expression of $\mathrm{Cks} 1$, we found also that cytoplasmic expression of $\mathrm{Cks} 1$, and its increasing cytoplasmic level, similarly to nuclear expression, correlated to melanocytic tumor progression, presence of poor-prognostic markers of melanoma, and worse survival.

Cks1 is ubiquitinated followed by proteasomal degradation, and some post-translational modifications, as observed in tumor cells, can modify Cks1 turnover [36]. Thus, increased cytoplasmic levels of Cks1 may represent high turnover of protein via the ubiquitination/protease pathway or its accumulation upon proteasomal blockade.

Cks1, as a cell control molecule, has been identified as a potential molecular target for cancer treatment since its silencing resulted in $\mathrm{G} 2 / \mathrm{M}$ arrest and apoptosis of 
A

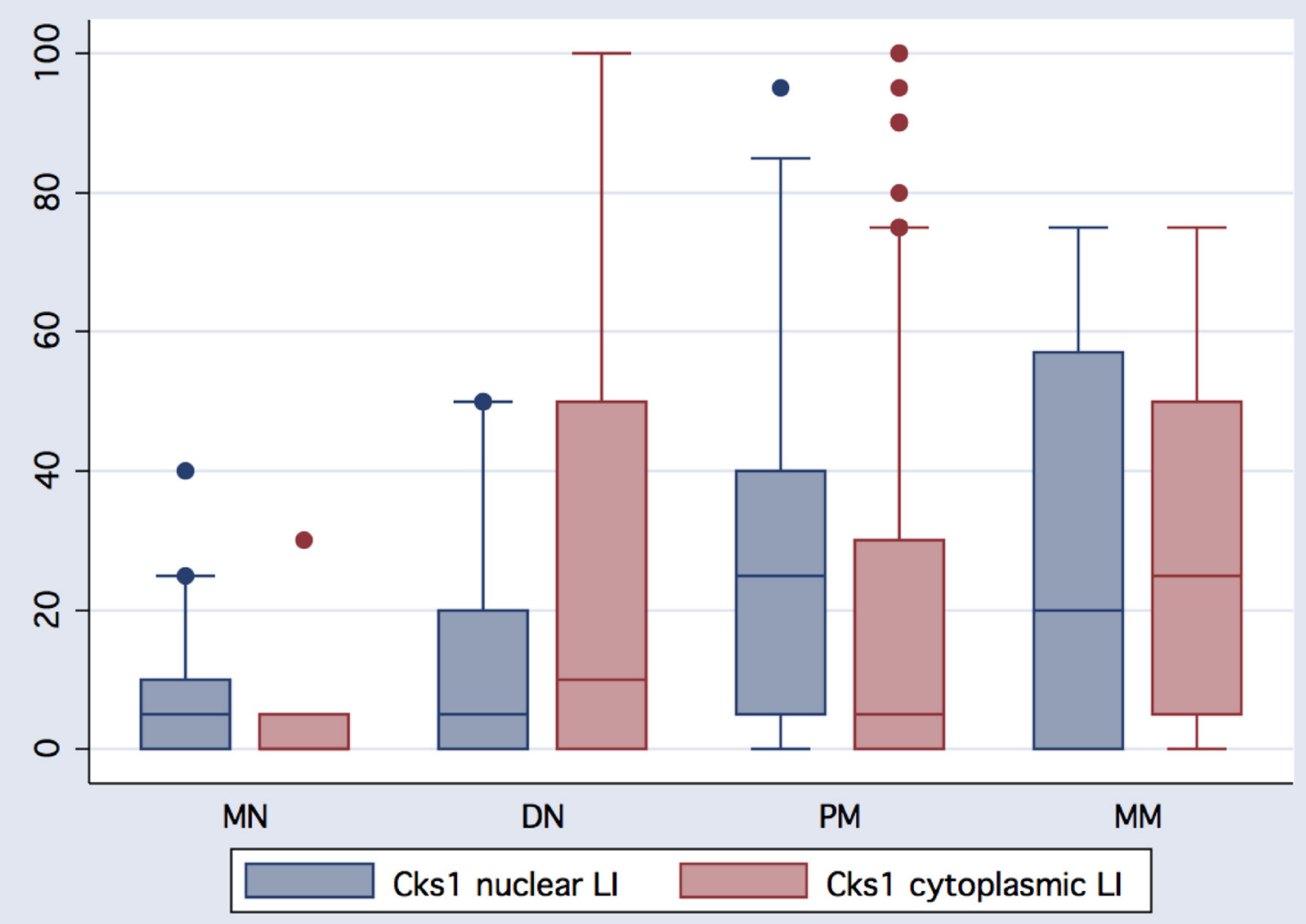

B

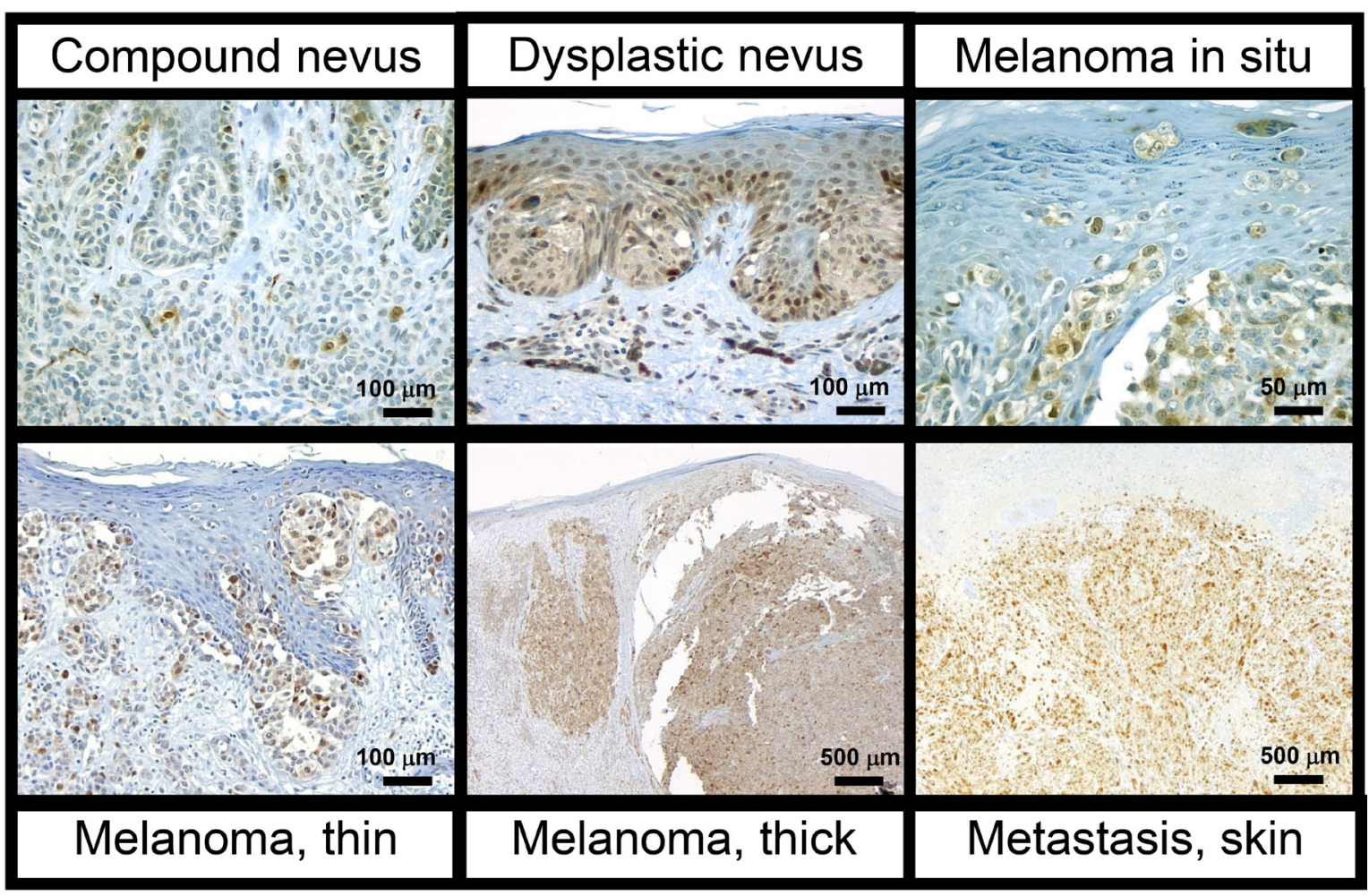

Figure 3: (A) Melanocytic lesions showed varying degrees of both cytoplasmic and nuclear Cks1 expression in the histologic stepwise progression: from banal common melanocytic nevi $(\mathrm{MN})$ to dysplastic melanocytic nevi to primary melanoma (PM), and metastatic metastatic melanoma. (B) Increasing nuclear and cytologic Cks1 expression with melanoma progression. 
Table 2: Cks1 expression in melanocytic nevi, primary cutaneous melanoma and metastatic melanoma

\begin{tabular}{|c|c|c|c|c|}
\hline & $\begin{array}{c}\text { Absolute } \\
\text { cytoplasmic } \\
\text { Cks1 } \\
\text { expression (\%) }\end{array}$ & $\begin{array}{c}\text { Cytoplasmic Cks1 } \\
\text { LI }\end{array}$ & $\begin{array}{c}\text { Absolute nuclear } \\
\text { Cks1 expression (\%) }\end{array}$ & Nuclear Cks1 LI \\
\hline Melanocytic nevi $(n=87)$ & 17.7 & $18,1 \pm 34,3(0-100)$ & 6.5 & $7.8 \pm 15.9(0-90)$ \\
\hline $\begin{array}{l}\text { Common acquired nevi ( } n= \\
33 \text { ) }\end{array}$ & 6.3 & $4.1 \pm 8.5(0-35)$ & 3.6 & $8.2 \pm 17.4(0-90)$ \\
\hline Dysplastic nevi $(n=29)$ & 1.7 & $1.7 \pm 4.1(0-20)$ & 1.0 & $3.1 \pm 2.5(0-5)$ \\
\hline Spitz Nevi $(n=11)$ & 45.0 & $45.0 \pm 45.9(0-100)$ & 20.1 & $20.5 \pm 26.1(0-90)$ \\
\hline Blue Nevi $(n=14)$ & 63.8 & $63.9 \pm 44.2(0-100)$ & 6. 0 & $6.4 \pm 14.3(0-50)$ \\
\hline Melanoma in situ $(n=8)$ & 10.4 & $11.3 \pm 16.6(0-50)$ & 12.9 & $13.8 \pm 11.9(3-35)$ \\
\hline $\begin{array}{l}\text { Radial growth phase } \\
\text { melanoma }(n=20)\end{array}$ & 22.3 & $22.3 \pm 32.4(0-100)$ & 7.7 & $8.8 \pm 22.0(0-100)$ \\
\hline $\begin{array}{l}\text { Vertical growth phase } \\
\text { melanoma }(n=143)\end{array}$ & 37.7 & $38.2 \pm 33.4(0-100)$ & 21.5 & $21.9 \pm 19.5(0-90)$ \\
\hline Nodular $(n=61)$ & 46.1 & $46.3 \pm 34.9(0-100)$ & 20.5 & $20.9 \pm 18.3(0-90)$ \\
\hline Superficial spreading $(n=38)$ & 28.6 & $29.1 \pm 30.4(0-100)$ & 16.6 & $17.1 \pm 18.9(0-80)$ \\
\hline Lentigo maligna $(n=20)$ & 29.1 & $29,8 \pm 32,8(0-100)$ & 26.4 & $27.0 \pm 20.2(0-70)$ \\
\hline Acral $(n=10)$ & 52.8 & $53,0 \pm 35,4(5-100)$ & 19.2 & $19.5 \pm 17.2(5-60)$ \\
\hline $\operatorname{Mucosal}(n=6)$ & 38.0 & $38.3 \pm 18,6(10-65)$ & 39.2 & $39.2 \pm 15.3(10-50)$ \\
\hline $\begin{array}{l}\text { Metastatic melanomas }(n= \\
40)\end{array}$ & 52.5 & $52.6 \pm 33.8(0-100)$ & 30.2 & $30.5 \pm 29.4(0-100)$ \\
\hline Lymph node $(n=26)$ & 54.8 & $55.0 \pm 34.5(0-100)$ & 32.0 & $32.3 \pm 32.2(0-100)$ \\
\hline Skin/soft tissue $(n=6)$ & 38.3 & $38.3 \pm 24.2(20-85)$ & 31.8 & $32.5 \pm 24.2(10-75)$ \\
\hline Visceral $(n=8)$ & 55.4 & $\begin{array}{c}55.6 \pm 26.8(20- \\
100)\end{array}$ & 23.1 & $23.1 \pm 24.6(0-70)$ \\
\hline
\end{tabular}

LI: labeling index + cells $/ 100$ tumor cells reported as mean \pm standard deviation; (range).

"Vertical growth phase melanoma" includes also desmoplastic $(n=6)$ and unclassified $(n=2)$ melanomas.

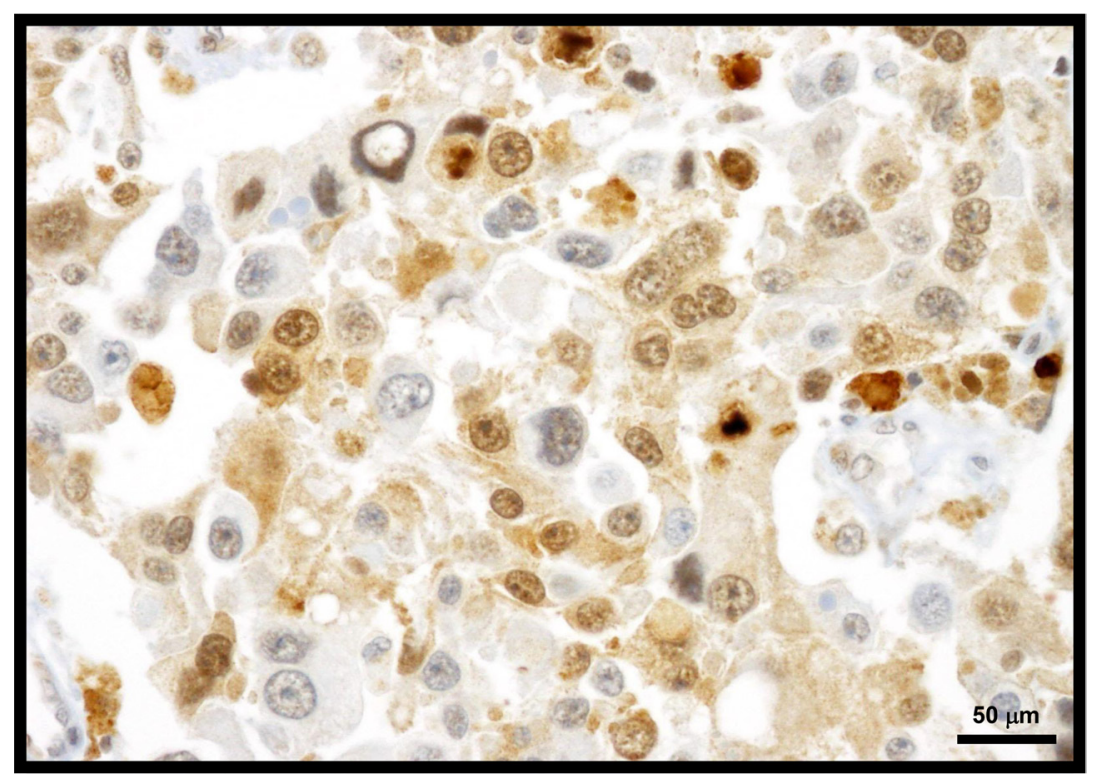

Figure 4: Melanomas typically express cytoplasmic and nuclear Cks1 protein. Exhibited herein is a metastatic melanoma to lymph node showing predominate cytoplasmic Cks1. 
lung cancer cells without affecting normal fibroblasts [37] and growth inhibition of cells of oral squamous carcinoma [38]. Also reported, over expression of Cks1 correlated to radiotherapy resistance, both in patients, and in experimental cell-based study of esophageal cancer. In addition, over expression of Cks1 closely associated with poor pathological features of esophageal carcinoma, including higher histologic tumor grade, regional lymph nodes invasion, and neoplastic embolus $[12,13]$.

Increased cell proliferation rate is a common and important feature of malignant lesions, and in melanoma cells the deregulation of different mechanisms of cellcycle control has been observed (reviewed in [39]. It was demonstrated that Cks1 is required for efficient Skp2dependent p27 ubiquitination and its degradation $[2,4]$. In different tumors, including melanomas, an inverse correlation between overexpression of $\mathrm{Cks} 1$ and reduced expression of cell-cycle inhibitor p27 has been shown $[9,14,28,40,41]$. Furthermore, decreased expression of p27 with the progression of tumors from nevi to melanomas, with lowest expression in metastatic melanomas, was reported [28, 42-44]. Some of these studies also revealed a negative correlation between reduced p27 expression and tumors thickness in nodular melanomas [42], as well as inverse correlation with diseasefree survival, supporting the prognostic significance of cell-controlling p27 expression in melanomas. Other authors have not found such an association [28, 45]. In melanomas, similar to Cks1, increasing expression of Skp2 with melanocytic tumor development from nevi to primary and metastatic melanomas was also demonstrated [28]. Silencing of Skp2 resulted in inhibition of melanoma tumor growth in vitro and in vivo [46]. Elevated Skp2 expression similarly predicted worse 10-year overall survival [28].

The reduced survival related to overexpression of Cks1 has also been observed in other tumors, including multiple myeloma [41], nasopharyngeal [47], gastric [8], colorectal [9, 10], esophageal [12] cancers and others. Correspondingly, in some studies increased expression of Cks1 was related to other clinico-pathomorphological features, such as poor differentiation [11] and lymph node metastasis [13, 47]. In nasopharyngeal tumors, increased expression of $\mathrm{Cks} 1$ has also been identified as an independent poor prognostic factor [47]. Our findings are concordant with results of other studies, as we have shown that Cks1 expression is not only a predictor of disease-free survival, but also a predictor of overall survival. Higher expression of Cks1 is associated with reduced diseasefree survival and overall survival in melanoma patients. Similarly, in our cohort, melanoma patients that developed metastases had elevated cytoplasmic Cks1 expression. Taken together, our findings point out the important role of $\mathrm{Cks} 1$ in melanoma biology and indicate the prognostic value of Cks1 in melanoma. In addition, $\mathrm{Cks} 1$ may be a potential molecule for targeted anti-melanoma treatment. However this concept should be confirmed using appropriate animal models including patient-derived orthotopic xenografts, which mimic clinical tumor growth and metastasis and have important clinical potential for melanoma patients [48-53]. Thus we also plan to perform

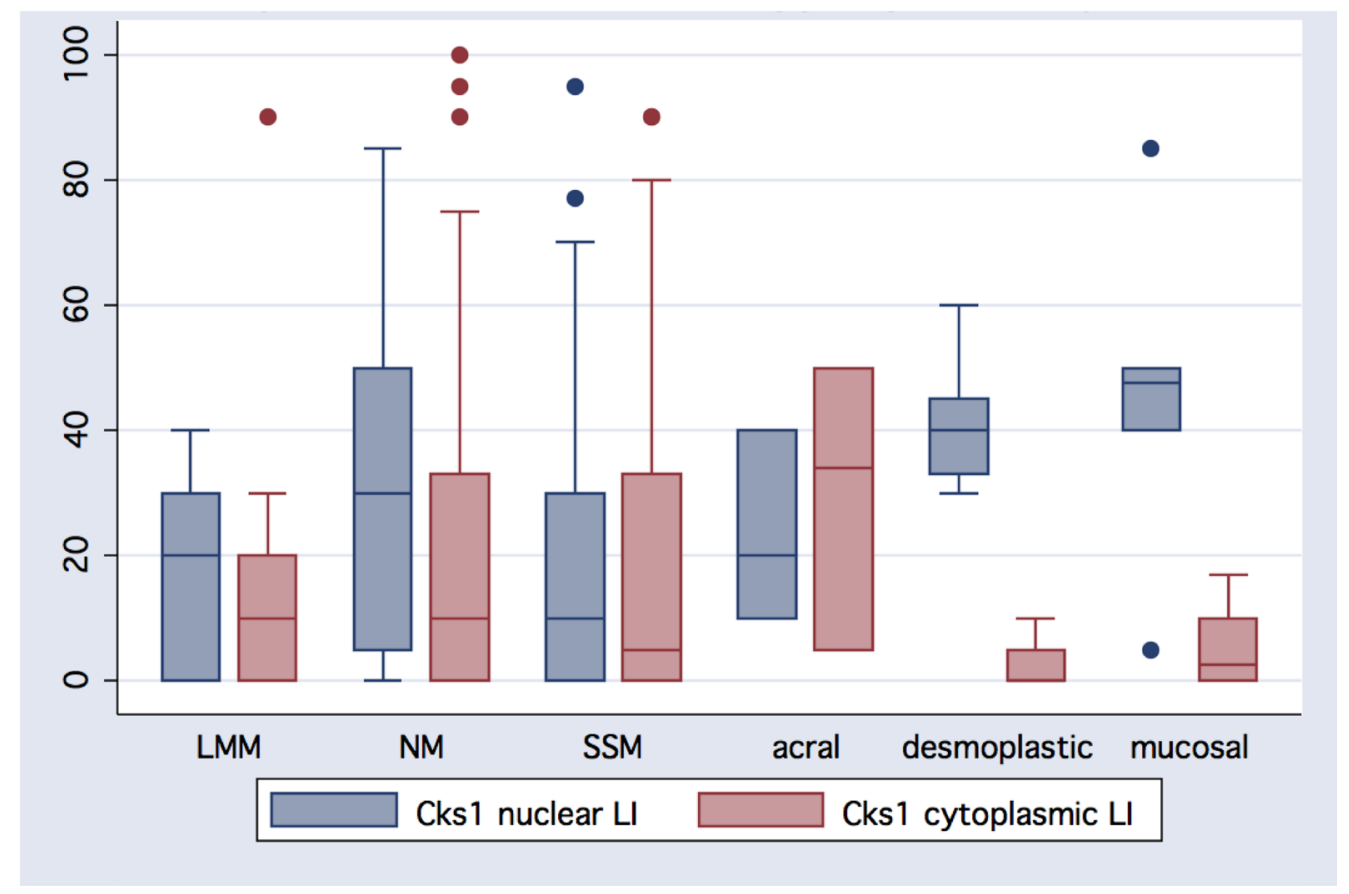

Figure 5: Heterogeneity of Cks1 nuclear and cytoplasmic expression amongst histologic melanoma subtypes. Except for acral melanomas, nuclear expression exceeds cytoplasmic reactivity in different histological types of melanoma: LMM (lentigo maligna melanoma); NM (nodular melanoma); SSM (superficial spreading melanoma). 
Table 3: Comparison of Cks1 LI with standard prognostic markers

\begin{tabular}{|c|c|c|c|}
\hline Category & & Cytoplasmic Cks1 LI (mean \pm SD) & Nuclear Cks1 LI (mean \pm SD) \\
\hline \multirow[t]{8}{*}{ AJCC Tumor stage } & $\mathrm{T} 1 \mathrm{a}(n=46)$ & $21.52 \pm 29.89$ & $14.02 \pm 23.87$ \\
\hline & $\mathrm{T} 1 \mathrm{~b}(n=3)$ & $15.00 \pm 18.03$ & $6.67 \pm 7.64$ \\
\hline & $\mathrm{T} 2 \mathrm{a}(n=33)$ & $33.64 \pm 35.52$ & $18.48 \pm 18.14$ \\
\hline & $\mathrm{T} 2 \mathrm{~b}(n=13)$ & $42.31 \pm 33.83$ & $20.38 \pm 15.34$ \\
\hline & $\mathrm{T} 3 \mathrm{a}(n=26)$ & $36.35 \pm 31.67$ & $22.31 \pm 14.51$ \\
\hline & $\mathrm{T} 3 \mathrm{~b}(n=15)$ & $50.00 \pm 28.22$ & $32.00 \pm 16.78$ \\
\hline & $\mathrm{T} 4 \mathrm{a}(n=7)$ & $47.14 \pm 33.02$ & $26.43 \pm 32.24$ \\
\hline & $\mathrm{T} 4 \mathrm{~b}(n=20)$ & $59.00 \pm 31.44$ & $26.25 \pm 18.06$ \\
\hline \multirow[t]{4}{*}{ Clark Level* $^{*}$} & Level $2(n=5)$ & $23.00 \pm 43.53$ & $21.00 \pm 44.22$ \\
\hline & Level $3(n=31)$ & $33.06 \pm 33.71$ & $11.77 \pm 16.81$ \\
\hline & Level $4(n=108)$ & $34.81 \pm 32.76$ & $21.85 \pm 18.64$ \\
\hline & Level $5(n=18)$ & $55.56 \pm 31.24$ & $26.67 \pm 23.26$ \\
\hline \multirow[t]{2}{*}{ Ulcer } & Absent $(n=116)$ & $29.53 \pm 32.43$ & $17.67 \pm 20.84$ \\
\hline & Present $(n=47)$ & $52.66 \pm 30.82$ & $26.81 \pm 17.21$ \\
\hline \multirow[t]{3}{*}{ Mitotic counts/10hpf } & $0(n=62)$ & $26.77 \pm 35.00$ & $12.90 \pm 20.68$ \\
\hline & $1-4(n=52)$ & $35.48 \pm 32.39$ & $20.48 \pm 15.38$ \\
\hline & $>4(n=48)$ & $49.90 \pm 28.61$ & $30.10 \pm 20.51$ \\
\hline \multirow[t]{2}{*}{ Vascular invasion } & $\operatorname{Absent}(n=135)$ & $35.19 \pm 34.11$ & $19.63 \pm 20.31$ \\
\hline & Present $(n=28)$ & $41.07 \pm 30.95$ & $23.57 \pm 19.90$ \\
\hline \multirow[t]{4}{*}{ Tumor vascularity ${ }^{*}$} & Absent $(n=33)$ & $29.24 \pm 33.94$ & $14.24 \pm 23.56$ \\
\hline & Sparse $(n=74)$ & $36.76 \pm 34.96$ & $19.80 \pm 18.57$ \\
\hline & Moderate $(n=37)$ & $44.32 \pm 33.27$ & $25.54 \pm 21.76$ \\
\hline & Prominent $(n=18)$ & $31.94 \pm 25.33$ & $23.89 \pm 14.30$ \\
\hline \multirow[t]{3}{*}{ Microsatellites } & Absent $(n=153)$ & $34.64 \pm 32.64$ & $19.87 \pm 19.67$ \\
\hline & Present $(n=10)$ & $66.67 \pm 36.31$ & $30.0 \pm 27.95$ \\
\hline & Absent $(n=30-)$ & $26.9 \pm 25.8$ & $44.4 \pm 25.8$ \\
\hline Tumor infiltrating lymphocytes & Non-brisk $(n=100)$ & $22.0 \pm 22.2$ & $36.4 \pm 33.4$ \\
\hline & Brisk (41) & $14.6 \pm 27.9$ & $27.9 \pm 33.7$ \\
\hline \multirow[t]{2}{*}{ Regression } & Absent $(n=126)$ & $38.69 \pm 34.24$ & $20.28 \pm 18.86$ \\
\hline & Present $(n=36)$ & $28.47 \pm 30.11$ & $20.97 \pm 24.75$ \\
\hline \multirow[t]{7}{*}{ AJCC Stages I and II } & Stage I $(n=82)$ & $26.16 \pm 32.28$ & $15.55 \pm 21.34$ \\
\hline & $\mathrm{Ia}(n=46)$ & $21.52 \pm 29.89$ & $14.02 \pm 23.87$ \\
\hline & $\mathrm{Ib}(n=36)$ & $32.08 \pm 34.63$ & $17.50 \pm 17.75$ \\
\hline & Stage II $(n=81)$ & $46.36 \pm 31.92$ & $25.12 \pm 17.92$ \\
\hline & IIa $(n=39)$ & $38.22 \pm 32.08$ & $21.67 \pm 14.61$ \\
\hline & $\operatorname{IIb}(n=22)$ & $49.09 \pm 29.06$ & $30.23 \pm 22.17$ \\
\hline & IIc $(n=20)$ & $59.00 \pm 31.44$ & $26.25 \pm 18.06$ \\
\hline \multirow[t]{3}{*}{ Type of (1st) melanoma recurrence } & Local $(n=6)$ & $38.33 \pm 34.22$ & $32.50 \pm 24.24$ \\
\hline & Regional $(n=26)$ & $55.00 \pm 37.47$ & $32.31 \pm 32.16$ \\
\hline & Distant $(n=8)$ & $55.63 \pm 26.78$ & $23.13 \pm 24.63$ \\
\hline \multirow[t]{4}{*}{ Outcome } & Alive without disease $(n=76)$ & $31.64 \pm 34.35$ & $15.07 \pm 17.97$ \\
\hline & Alive with disease $(n=15)$ & $44.00 \pm 33.60$ & $29.33 \pm 20.69$ \\
\hline & Dead without disease $(n=21)$ & $35.71 \pm 35.96$ & $20.71 \pm 27.49$ \\
\hline & Dead with disease $(n=45)$ & $43.11 \pm 29.97$ & $27.00 \pm 18.35$ \\
\hline
\end{tabular}

LI: labeling index + cells $/ 100$ tumor cells reported as mean \pm standard deviation

"Per criteria of Kashani-Sabet M et al. [66]

NS - not statistically significant 
Table 4: Correlation of Cks1 with other clinicopathologic factors in melanoma patients

\begin{tabular}{lcccc}
\hline \multirow{2}{*}{ Category } & \multicolumn{2}{c}{ Cytoplasmic Cks1 LI } & \multicolumn{2}{c}{ Nuclear Cks1 LI } \\
\cline { 2 - 5 } & $\boldsymbol{r}$ & $\boldsymbol{p}$ & $\boldsymbol{r}$ & $\boldsymbol{p}$ \\
\hline Age & $\mathrm{NS}$ & $\mathrm{NS}$ & $\mathrm{NS}$ & 0.028 \\
Sex & $\mathrm{NS}$ & $\mathrm{NS}$ & 0.15 & $\mathrm{NS}$ \\
Site & $\mathrm{NS}$ & $\mathrm{NS}$ & $\mathrm{NS}$ & 0.005 \\
Breslow thickness & 0.35 & $<0.0001$ & 0.20 & 0.011 \\
Clark Level & 0.17 & 0.016 & 0.18 & 0.004 \\
Ulcer & 0.31 & $<0.0001$ & 0.21 & 0.0002 \\
Mitotic counts/10 hpf & 0.27 & $<0.0001$ & 0.33 & 0.0007 \\
Tumor infiltrating lymphocytes & -0.18 & 0.011 & -0.25 & $\mathrm{NS}$ \\
Vascular invasion & $\mathrm{NS}$ & $\mathrm{NS}$ & $\mathrm{NS}$ & 0.013 \\
Tumor vascularity & $\mathrm{NS}$ & $\mathrm{NS}$ & 0.18 & $\mathrm{~N}$ \\
AJCC stage & 0.36 & $<0.0001$ & 0.26 & $\mathrm{NS}$ \\
Microsatellites & 0.22 & 0.0024 & $\mathrm{NS}$ & $\mathrm{N}$ \\
Regression & $\mathrm{NS}$ & $\mathrm{NS}$ & $\mathrm{NS}$ & $\mathrm{NS}$ \\
Associated nevus & -0.17 & 0.016 & -0.16 & 0.0001 \\
Pigmentation-RGP & $\mathrm{NS}$ & $\mathrm{NS}$ & $\mathrm{NS}$ & 0.04 \\
Pigmentation-VGP & -0.21 & 0.01 & -0.33 & 0.018 \\
Pigmentation-metastases & 0.36 & 0.03 & 0.34 & 0.023 \\
Solar elastosis & $\mathrm{NS}$ & $\mathrm{NS}$ & 0.17 & \\
Spindle melanocytes & $\mathrm{NS}$ & $\mathrm{NS}$ & 0.17 & \\
\hline
\end{tabular}

RGP: radial growth phase; VGP: vertical growth phase

an in depth mechanism oriented studies to define in details the role of CKS1 in melanoma progression and metastases and its usefulness as a target in anti-melanoma treatment using patient-derived orthotopic xenografts and transgenic mice.

Furthermore, this study showed relationships between melanoma stage and degree of tumor melaninization. First, a lack of relation between melanin pigmentation and Csk 1 expression in radial growth phase melanomas; second, a negative correlation between nuclear Cks1 expression and vertical growth phase melanoma; and third, a positive correlation of melanin with nuclear and cytoplasmic Cks1 in melanized melanoma metastases. This spectrum suggests that melanogenic apparatus may affect the function and processing of Cks1 depending on the stage of tumor progression. It must be noted that melanogenesis may affect metabolic status and behavior of melanoma cells in a complex manner [54-59]. In addition, our previous study showed that higher melanin levels were associated with poorer prognosis and outcome following radiotherapy in melanoma patients $[60,61]$. Animalbased study has revealed that spontaneous apoptosis of amelanotic melanoma cells is reduced in comparison to melanotic melanomas, and that pigmented melanoma cells are more resistant to induced apoptosis [62]. This is consistent, with experimental findings that inhibition of melanogenesis can act as sensitizer to radiation and cyclophosphamide induced toxicity or immune destruction of melanoma cells $[63,64]$. Therefore, the potential effect of active melanogenesis or its intermediates on Cks1 expression and function deserves further careful and an in-depth investigation.

\section{CONCLUSIONS}

In summary, nuclear expression of Cks1 increased with the stage of melanoma progression and correlated with poor overall survival. Cytoplasmic expression of Cks1 may represent high turnover of protein via the ubiquitination/ protease pathway and is likely a marker of melanoma cell proliferation. These results indicate a role for Cks1 in the pathogenesis of melanoma. Further exploration of this topic will include multivariate survival analysis to determine if Cks1 is an independent prognostic variable and to evaluate whether Cks1 expression segregates with the presence or absence of specific gene mutations involved in melanoma such as BRAF and NRAS. 
Table 5: Predictors of prognosis by univariate analysis

\begin{tabular}{|c|c|c|c|c|c|c|}
\hline & \multicolumn{3}{|c|}{ Disease-free survival } & \multicolumn{3}{|c|}{ Overall survival } \\
\hline & Hazard ratio & $\begin{array}{l}95 \% \text { Conf. } \\
\text { Interval }\end{array}$ & $p$ & Hazard ratio & $\begin{array}{c}95 \% \text { Conf. } \\
\text { Interval }\end{array}$ & $p$ \\
\hline Age & 1.01 & $1.00-1.02$ & 0.055 & 1.05 & $1.02-1.07$ & 0.0001 \\
\hline AJCC stage (I and II) & 1.97 & $1.58-2.44$ & 0.0001 & 1.93 & $1.49-2.50$ & 0.0001 \\
\hline Angioinvasion & 5.44 & $2.94-10.09$ & 0.0001 & 6.23 & $3.10-12.50$ & 0.0001 \\
\hline Associated nevus & 0.79 & $0.42-1.47$ & 0.46 & 0.97 & $0.48-1.99$ & 0.64 \\
\hline Cks1 cytoplasmic $(20 \%)$ & 2.20 & $1.23-3.94$ & 0.008 & 2.169 & $1.09-4.28$ & 0.027 \\
\hline Cks1 nuclear $(20 \%)$ & 3.47 & $1.96-6.12$ & 0.0001 & 3.51 & $1.80-6.85$ & 0.0001 \\
\hline Clark's level & 4.33 & $2.36-7.97$ & 0.0001 & 3.23 & $1.70-6.15$ & 0.0001 \\
\hline Depth & 1.34 & $1.19-1.51$ & 0.0001 & 1.28 & $1.11-1.48$ & 0.001 \\
\hline Mitosis & 1.12 & $1.09-1.61$ & 0.0001 & 1.11 & $1.06-1.15$ & 0.0001 \\
\hline Pigmentation - stage I & 2.698 & $0.6564-24.46$ & 0.1326 & 2.567 & $0.4167-31.92$ & 0.2424 \\
\hline Pigmentation - stage II & 0.8327 & $0.4188-1.638$ & 0.5882 & 0.7925 & $0.3481-1.735$ & 0.5380 \\
\hline Pigmentation - stage III & 1.166 & $0.4007-3.437$ & 0.7705 & 0.9635 & $0.3537-2.620$ & 0.9406 \\
\hline Pigmentation - stage IV & - & - & - & 2.113 & $0.7163-10.60$ & 0.1403 \\
\hline Regression & 0.56 & $0.26-1.20$ & 0.14 & 0.46 & $0.18-1.20$ & 0.11 \\
\hline Sex & 1.36 & $0.72-2.56$ & 0.35 & 1.64 & $0.75-3.63$ & 0.21 \\
\hline Site & 1.00 & $0.77-1.28$ & 0.97 & 0.64 & $0.70-1.27$ & 0.68 \\
\hline TILS & 0.98 & $0.97-0.99$ & 0.0001 & 0.98 & $0.97-0.99$ & 0.003 \\
\hline Tumor vascularity & 1.82 & $1.38-2.40$ & 0.0001 & 2.06 & $1.48-2.85$ & 0.0001 \\
\hline Ulceration & 3.97 & $2.25-7.02$ & 0.0001 & 4.34 & $2.23-8.47$ & 0.0001 \\
\hline
\end{tabular}

TILS: tumor infiltrating lymphocytes. Bold significant $(\leq 0.05$; italics, trend $(<0.10)$

AJCC: American Joint Committee on Cancer. LI: labeling index.

\section{MATERIALS AND METHODS}

\section{Samples}

Two hundred and ninety-eight paraffin blocks of melanocytic lesions were retrieved for this study from the files of the Department of Pathology, Albany Medical Center Hospital; Samuel Stratton Veterans Administration Medical Center; Emory University, Department of Pathology; and UConn Health. These samples consisted of 87 melanocytic nevi (9 junctional, 14 compound, 10 intradermal, 11 Spitz nevi, 29 dysplastic per criteria of Clemente et al. [67], and 14 blue nevi were examined), 8 melanoma in situ, 163 primary melanomas, and 40 metastatic melanomas (26 regional lymph node, 6 skin and soft tissue, and 8 visceral metastases). Clinicopathologic data were retrieved from reports (histologic diagnosis and melanoma histologic staging features were reviewed on each). Survival data were retrieved from the Tumor Registries at all 4 institutions. This study was approved by the institutional review board.
The primary melanomas patients had a mean age of 60 years (range 15-93 years old) and comprised of 53 females and 112 males (ages were not available for 6 patients). Clinical follow-up was available on 158 primary melanomas patients with a mean of 58 months of observation (range 6-225 months). Twenty-two of the primary melanomas patients had metastases available for immunohistochemical analysis. In addition, primary melanomas were classified by the updated AJCC tumornode-metastasis and staging criteria [65]. The primary melanomas consisted of 46 stage Ia (46 T1a), 36 stage $\mathrm{Ib}$ ( 3 T1b, 33 T2a), 39 stage IIa (13 T2b, 26 T3a), 22 stage IIb (15 T3b, 7 T4a), and 20 stage IIc (20 T4b) melanomas.

\section{Immunohistochemistry}

Expression of Cks1 (Zymed, San Francisco, CA; 1:50) was evaluated by immunohistochemistry. The frequency and intensity of cytoplasmic and nuclear expression was scored as a labeling index. This data was 
correlated with clinical, pathologic, and outcome data. Melanocytic nevi served as a control. Non-tumor elements (sweat glands, lymphocytes) also served as a control and exhibited Cks1 staining.

\section{Statistical analysis}

Statistical analysis was carried out with the STATA (College Station, TX) statistical package. Differences between groups were tested by the chi-squared test for dichotomous variables and by the Student's $t$-test for continuous variables. Correlations between study variables were examined by linear regression and pairwise covariance methods. Survival analysis was performed using the Kaplan Meier method. In addition, univariate and multivariate Cox proportional hazards models were applied to assess the effect of CKS1 expression and other variables and disease-free survival and overall survival. GraphPad Prism 5.0 (La Jolla, CA) was used to prepare survival graphs. The criterion for significance was $p \leq 0.05$.
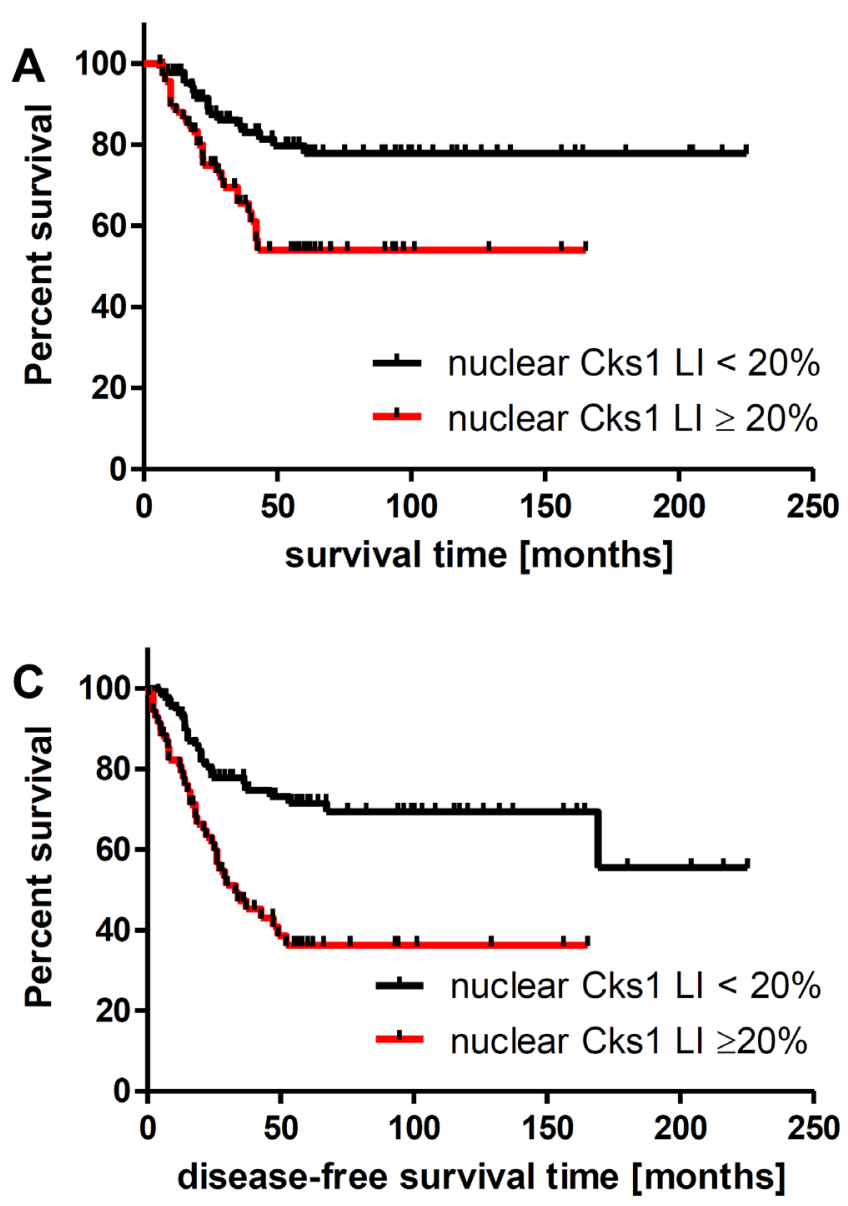

\section{Abbreviations}

AJCC: American Joint Commission on Cancer; CDK: cyclin-dependent kinase; Cks1: cyclin-dependent kinase subunit 1; ERK1/2: extracellular signal-regulated kinase 1/2; MAPK: mitogen-activated protein kinase; MEK: mitogen-activated protein kinase kinase; Skp2: S phase kinase-associated protein 2.

\section{Author contributions}

AAB - analyzed the data, interpreted the results and wrote the manuscript; AA - performed experiments, revised the manuscript; $\mathrm{CC}$ - collecting the data, revised the manuscript; $\mathrm{GC}$ - collecting the data, revised the manuscript; AJP - collecting the data, revised the manuscript; MM collecting the data, revised the manuscript; ATS - interpreted the results, revised and approved the final version of the manuscript; JAC - designed the experiments, analyzed the data, interpreted the results, revised and approved the final version of the manuscript.
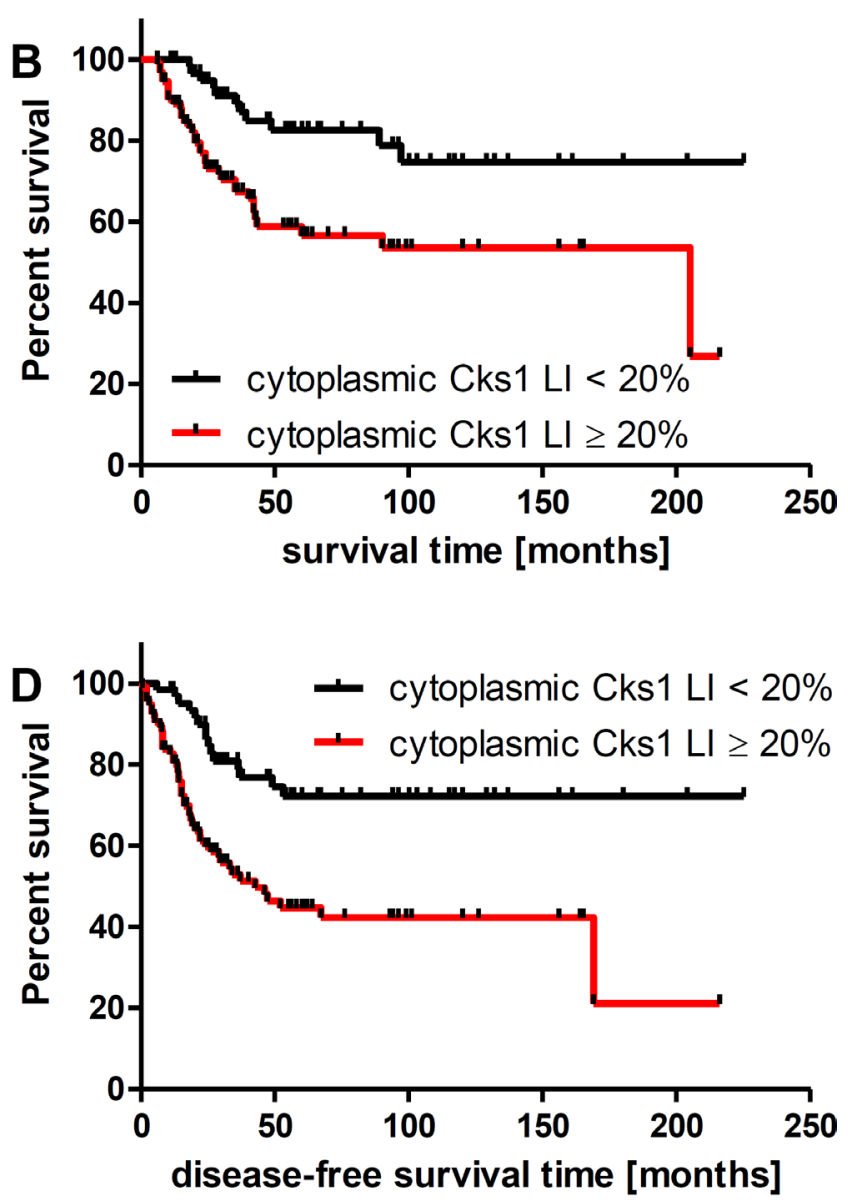

Figure 6: Five-year overall survival (A, B) and disease free survival (C, D). Significant decreased 5 year overall survival was associated with nuclear (A) and cytoplasmic (B) Cks1 labeling index of 20 or greater in primary melanoma (54\% versus $78 \%$, and $27 \%$ versus $75 \%$, respectively). Significant decreased disease free survival was associated with nuclear (C) and cytoplasmic (D) Cks1 labeling index of 20 or greater in primary melanoma (36\% versus $55 \%$, and $21 \%$ versus $72 \%$, respectively). LI - labeling index. 


\section{ACKNOWLEDGMENTS}

This work was presented in part at the XXX Colloquium of the International Society of Dermatopathology, Santiago, Chile, October 29, 2009

\section{CONFLICTS OF INTEREST}

The authors of have no conflicts of interest to disclose.

\section{FUNDING}

This study was supported by grants from NIH (R01 CA125103) and (R21AR066505, 1R01AR056666 and 1 R01AR071189 to ATS), by the clinical revenues and generous donors to the Divisions of Dermatology and Dermatopathology, Department of Pathology, Albany Medical College and grant 2014/15/B/NZ4/00751 from National Science Centre, Poland to AAB.

\section{REFERENCES}

1. Podust VN, Brownell JE, Gladysheva TB, Luo RS, Wang C, Coggins MB, Pierce JW, Lightcap ES, Chau V. A Nedd8 conjugation pathway is essential for proteolytic targeting of p27Kip1 by ubiquitination. Proc Natl Acad Sci U S A. 2000; 97:4579-4584.

2. Ganoth D, Bornstein G, Ko TK, Larsen B, Tyers M, Pagano $\mathrm{M}$, Hershko A. The cell-cycle regulatory protein $\mathrm{Cks} 1$ is required for $\mathrm{SCF}(\mathrm{Skp} 2)$-mediated ubiquitinylation of $\mathrm{p} 27$. Nat Cell Biol. 2001; 3:321-324.

3. Richardson HE, Stueland CS, Thomas J, Russell P, Reed SI. Human cDNAs encoding homologs of the small p34Cdc28/ Cdc2-associated protein of Saccharomyces cerevisiae and Schizosaccharomyces pombe. Genes Dev. 1990; 4:1332-1344.

4. Spruck C, Strohmaier H, Watson M, Smith AP, Ryan A, Krek TW, Reed SI. A CDK-independent function of mammalian Cks1: targeting of $\mathrm{SCF}(\mathrm{Skp} 2)$ to the $\mathrm{CDK}$ inhibitor p27Kip1. Mol Cell. 2001; 7:639-650.

5. Bhatt KV, Hu R, Spofford LS, Aplin AE. Mutant B-RAF signaling and cyclin D1 regulate $\mathrm{Cks} 1 / \mathrm{S}$-phase kinaseassociated protein 2-mediated degradation of p27Kip1 in human melanoma cells. Oncogene. 2007; 26:1056-1066.

6. $\mathrm{Hu} \mathrm{R}$, Aplin AE. alphaB-crystallin is mutant B-RAF regulated and contributes to cyclin D1 turnover in melanocytic cells. Pigment Cell Melanoma Res. 2010; 23:201-209.

7. Liberal V, Martinsson-Ahlzen HS, Liberal J, Spruck CH, Widschwendter M, McGowan CH, Reed SI. Cyclindependent kinase subunit (Cks) 1 or Cks2 overexpression overrides the DNA damage response barrier triggered by activated oncoproteins. Proc Natl Acad Sci U S A. 2012; 109:2754-2759.

8. Masuda TA, Inoue H, Nishida K, Sonoda H, Yoshikawa Y, Kakeji Y, Utsunomiya T, Mori M. Cyclin-dependent kinase 1 gene expression is associated with poor prognosis in gastric carcinoma. Clin Cancer Res. 2003; 9:5693-5698.

9. Shapira M, Ben-Izhak O, Bishara B, Futerman B, Minkov I, Krausz MM, Pagano M, Hershko DD. Alterations in the expression of the cell cycle regulatory protein cyclin kinase subunit 1 in colorectal carcinoma. Cancer. 2004; 100:1615-1621.

10. Shapira M, Ben-Izhak O, Linn S, Futerman B, Minkov I, Hershko DD. The prognostic impact of the ubiquitin ligase subunits Skp2 and Cks1 in colorectal carcinoma. Cancer. 2005; 103:1336-1346.

11. Shen DY, Fang ZX, You P, Liu PG, Wang F, Huang CL, Yao XB, Chen ZX, Zhang ZY. Clinical significance and expression of cyclin kinase subunits 1 and 2 in hepatocellular carcinoma. Liver Int. 2009; 30:119-125.

12. Wang JJ, Fang ZX, Ye HM, You P, Cai MJ, Duan HB, Wang F, Zhang ZY. Clinical significance of overexpressed cyclindependent kinase subunits 1 and 2 in esophageal carcinoma. Dis Esophagus. 2013; 26:729-736.

13. Wang XC, Tian LL, Tian J, Li D, Wang Y, Wu H, Zheng $\mathrm{H}$, Meng AM. Overexpression of Cks1 increases the radiotherapy resistance of esophageal squamous cell carcinoma. J Radiat Res. 2012; 53:72-78.

14. Keller UB, Old JB, Dorsey FC, Nilsson JA, Nilsson L, MacLean KH, Chung L, Yang C, Spruck C, Boyd K, Reed SI, Cleveland JL. Myc targets Cks1 to provoke the suppression of $\mathrm{p} 27 \mathrm{Kip} 1$, proliferation and lymphomagenesis. EMBO J. 2007; 26:2562-2574.

15. Balog ER, Saetern OC, Finch W, Hoeft CO, Thai V, Harvey SL, Kellogg DR, Rubin SM. The structure of a monomeric mutant $\mathrm{Cks}$ protein reveals multiple functions for a conserved hinge-region proline. J Mol Biol. 2011; 411:520-528.

16. Conner SR, Scott G, Aplin AE. Adhesion-dependent activation of the ERK1/2 cascade is by-passed in melanoma cells. J Biol Chem. 2003; 278:34548-34554.

17. Davies H, Bignell GR, Cox C, Stephens P, Edkins S, Clegg S, Teague J, Woffendin H, Garnett MJ, Bottomley W, Davis N, Dicks E, Ewing R, et al. Mutations of the BRAF gene in human cancer. Nature. 2002; 417:949-954.

18. Collisson EA, De A, Suzuki H, Gambhir SS, Kolodney MS. Treatment of metastatic melanoma with an orally available inhibitor of the Ras-Raf-MAPK cascade. Cancer Res. 2003; 63:5669-5673.

19. Hingorani SR, Jacobetz MA, Robertson GP, Herlyn M, Tuveson DA. Suppression of BRAF(V599E) in human melanoma abrogates transformation. Cancer Res. 2003; 63:5198-5202. 
20. Karasarides M, Chiloeches A, Hayward R, Niculescu-Duvaz D, Scanlon I, Friedlos F, Ogilvie L, Hedley D, Martin J, Marshall CJ, Springer CJ, Marais R. B-RAF is a therapeutic target in melanoma. Oncogene. 2004; 23:6292-6298.

21. Sumimoto H, Miyagishi M, Miyoshi H, Yamagata S, Shimizu A, Taira K, Kawakami Y. Inhibition of growth and invasive ability of melanoma by inactivation of mutated BRAF with lentivirus-mediated RNA interference. Oncogene. 2004; 23:6031-6039.

22. Bhatt KV, Spofford LS, Aram G, McMullen M, Pumiglia $\mathrm{K}$, Aplin AE. Adhesion control of cyclin D1 and p27Kip1 levels is deregulated in melanoma cells through BRAFMEK-ERK signaling. Oncogene. 2005; 24:3459-3471.

23. Sharma A, Trivedi NR, Zimmerman MA, Tuveson DA, Smith CD, Robertson GP. Mutant V599EB-Raf regulates growth and vascular development of malignant melanoma tumors. Cancer Res. 2005; 65:2412-2421.

24. Marin YE, Namkoong J, Cohen-Solal K, Shin SS, Martino JJ, Oka M, Chen S. Stimulation of oncogenic metabotropic glutamate receptor 1 in melanoma cells activates ERK1/2 via PKCepsilon. Cell Signal. 2006; 18:1279-1286.

25. Satyamoorthy K, Li G, Gerrero MR, Brose MS, Volpe P, Weber BL, Van Belle P, Elder DE, Herlyn M. Constitutive mitogen-activated protein kinase activation in melanoma is mediated by both BRAF mutations and autocrine growth factor stimulation. Cancer Res. 2003; 63:756-759.

26. Krek W. Proteolysis and the G1-S transition: the SCF connection. Curr Opin Genet Dev. 1998; 8:36-42.

27. Patton EE, Willems AR, Tyers M. Combinatorial control in ubiquitin-dependent proteolysis: don't Skp the F-box hypothesis. Trends Genet. 1998; 14:236-243.

28. Li Q, Murphy M, Ross J, Sheehan C, Carlson JA. Skp2 and p27kip1 expression in melanocytic nevi and melanoma: an inverse relationship. J Cutan Pathol. 2004; 31:633-642.

29. Carrano AC, Eytan E, Hershko A, Pagano M. SKP2 is required for ubiquitin-mediated degradation of the CDK inhibitor p27. Nat Cell Biol. 1999; 1:193-199.

30. Kamura T, Hara T, Kotoshiba S, Yada M, Ishida N, Imaki H, Hatakeyama S, Nakayama K, Nakayama KI. Degradation of p57Kip2 mediated by SCFSkp2-dependent ubiquitylation. Proc Natl Acad Sci U S A. 2003; 100:10231-10236.

31. Nakayama K, Nagahama H, Minamishima YA, Miyake S, Ishida N, Hatakeyama S, Kitagawa M, Iemura S, Natsume T, Nakayama KI. Skp2-mediated degradation of p27 regulates progression into mitosis. Dev Cell. 2004; 6:661-672.

32. Bornstein G, Bloom J, Sitry-Shevah D, Nakayama K, Pagano M, Hershko A. Role of the SCFSkp2 ubiquitin ligase in the degradation of p21Cip1 in S phase. J Biol Chem. 2003; 278:25752-25757.

33. Mendez J, Zou-Yang XH, Kim SY, Hidaka M, Tansey WP, Stillman B. Human origin recognition complex large subunit is degraded by ubiquitin-mediated proteolysis after initiation of DNA replication. Mol Cell. 2002; 9:481-491.
34. Nakayama K, Nagahama H, Minamishima YA, Matsumoto M, Nakamichi I, Kitagawa K, Shirane M, Tsunematsu R, Tsukiyama T, Ishida N, Kitagawa M, Hatakeyama $\mathrm{S}$. Targeted disruption of Skp2 results in accumulation of cyclin E and p27(Kip1), polyploidy and centrosome overduplication. EMBO J. 2000; 19:2069-2081.

35. $\mathrm{Hu} \mathrm{R}, \mathrm{Aplin} \mathrm{AE}$. Skp2 regulates G2/M progression in a $\mathrm{p} 53-$ dependent manner. Mol Biol Cell. 2008; 19:4602-4610.

36. Khattar V, Thottassery JV. Cks1 proteasomal turnover is a predominant mode of regulation in breast cancer cells: Role of key tyrosines and lysines. Int J Oncol. 2015; 46:395-406.

37. Tsai YS, Chang HC, Chuang LY, Hung WC. RNA silencing of $\mathrm{Cks} 1$ induced G2/M arrest and apoptosis in human lung cancer cells. IUBMB Life. 2005; 57:583-589.

38. Kitajima S, Kudo Y, Ogawa I, Bashir T, Kitagawa M, Miyauchi M, Pagano M, Takata T. Role of Cks1 overexpression in oral squamous cell carcinomas: cooperation with Skp2 in promoting p27 degradation. Am J Pathol. 2004; 165:2147-2155.

39. Li W, Sanki A, Karim RZ, Thompson JF, Soon Lee C, Zhuang L, McCarthy SW, Scolyer RA. The role of cell cycle regulatory proteins in the pathogenesis of melanoma. Pathology. 2006; 38:287-301.

40. Lan Y, Zhang Y, Wang J, Lin C, Ittmann MM, Wang F. Aberrant expression of $\mathrm{Cks} 1$ and $\mathrm{Cks} 2$ contributes to prostate tumorigenesis by promoting proliferation and inhibiting programmed cell death. Int J Cancer. 2008; 123:543-551.

41. Chang H, Jiang N, Jiang H, Saha MN, Qi C, Xu W, Reece D. CKS1B nuclear expression is inversely correlated with p27Kip1 expression and is predictive of an adverse survival in patients with multiple myeloma. Haematologica. 2010; 95:1542-1547.

42. Florenes VA, Maelandsmo GM, Kerbel RS, Slingerland JM, Nesland JM, Holm R. Protein expression of the cellcycle inhibitor p27Kip1 in malignant melanoma: inverse correlation with disease-free survival. Am J Pathol. 1998; 153:305-312.

43. Alonso SR, Ortiz P, Pollan M, Perez-Gomez B, Sanchez L, Acuna MJ, Pajares R, Martinez-Tello FJ, Hortelano CM, Piris MA, Rodriguez-Peralto JL. Progression in cutaneous malignant melanoma is associated with distinct expression profiles: a tissue microarray-based study. Am J Pathol. 2004; 164:193-203.

44. Chen G, Cheng Y, Zhang Z, Martinka M, Li G. Prognostic significance of cytoplasmic p27 expression in human melanoma. Cancer Epidemiol Biomarkers Prev. 2011; 20:2212-2221.

45. Sanki A, Li W, Colman M, Karim RZ, Thompson JF, Scolyer RA. Reduced expression of p16 and p27 is correlated with tumour progression in cutaneous melanoma. Pathology. 2007; 39:551-557. 
46. Katagiri Y, Hozumi Y, Kondo S. Knockdown of Skp2 by siRNA inhibits melanoma cell growth in vitro and in vivo. $\mathrm{J}$ Dermatol Sci. 2006; 42:215-224.

47. Xu L, Fan S, Zhao J, Zhou P, Chu S, Luo J, Wen Q, Chen L, Wen S, Wang L, Shi L. Increased expression of Cks1 protein is associated with lymph node metastasis and poor prognosis in nasopharyngeal carcinoma. Diagn Pathol. $2017 ; 12: 2$.

48. Kawaguchi K, Igarashi K, Li S, Han Q, Tan Y, Kiyuna T, Miyake K, Murakami T, Chmielowski B, Nelson SD, Russell TA, Dry SM, Li Y, et al. Combination treatment with recombinant methioninase enables temozolomide to arrest a BRAF V600E melanoma in a patient-derived orthotopic xenograft (PDOX) mouse model. Oncotarget. 2017; 8:85516-85525. http://doi.org/10.18632/oncotarget.20231.

49. Kawaguchi K, Igarashi K, Murakami T, Chmielowski B, Kiyuna T, Zhao M, Zhang Y, Singh A, Unno M, Nelson SD, Russell TA, Dry SM, Li Y, et al. Tumor-targeting Salmonella typhimurium A1-R combined with temozolomide regresses malignant melanoma with a BRAF-V600E mutation in a patient-derived orthotopic xenograft (PDOX) model. Oncotarget. 2016; 7:85929-85936. http://doi.org/10.18632/ oncotarget.13231.

50. Kawaguchi K, Igarashi K, Murakami T, Kiyuna T, Zhao M, Zhang Y, Nelson SD, Russell TA, Dry SM, Singh AS, Chmielowski B, Li Y, Unno M, et al. Salmonella typhimurium A1-R targeting of a chemotherapy-resistant BRAF-V600E melanoma in a patient-derived orthotopic xenograft (PDOX) model is enhanced in combination with either vemurafenib or temozolomide. Cell Cycle. 2017; 16:1288-1294.

51. Kawaguchi K, Igarashi K, Murakami T, Zhao M, Zhang Y, Chmielowski B, Kiyuna T, Nelson SD, Russell TA, Dry SM, Li Y, Unno M, Eilber FC, Hoffman RM. TumorTargeting Salmonella typhimurium A1-R Sensitizes Melanoma With a BRAF-V600E Mutation to Vemurafenib in a Patient-Derived Orthotopic Xenograft (PDOX) Nude Mouse Model. J Cell Biochem. 2017; 118:2314-2319.

52. Kawaguchi K, Murakami T, Chmielowski B, Igarashi K, Kiyuna T, Unno M, Nelson SD, Russell TA, Dry SM, Li Y, Eilber FC, Hoffman RM. Vemurafenib-resistant BRAF-V600E-mutated melanoma is regressed by MEKtargeting drug trametinib, but not cobimetinib in a patientderived orthotopic xenograft (PDOX) mouse model. Oncotarget. 2016; 7:71737-71743. http://doi.org/10.18632/ oncotarget. 12328.

53. Yamamoto M, Zhao M, Hiroshima Y, Zhang Y, Shurell E, Eilber FC, Bouvet M, Noda M, Hoffman RM. Efficacy of Tumor-Targeting Salmonella A1-R on a Melanoma PatientDerived Orthotopic Xenograft (PDOX) Nude-Mouse Model. PLoS One. 2016; 11:e0160882.

54. Li W, Slominski R, Slominski AT. High-resolution magic angle spinning nuclear magnetic resonance analysis of metabolic changes in melanoma cells after induction of melanogenesis. Anal Biochem. 2009; 386:282-284.
55. Slominski A, Kim TK, Brozyna AA, Janjetovic Z, Brooks DL, Schwab LP, Skobowiat C, Jozwicki W, Seagroves $\mathrm{TN}$. The role of melanogenesis in regulation of melanoma behavior: melanogenesis leads to stimulation of HIF-1alpha expression and HIF-dependent attendant pathways. Arch Biochem Biophys. 2014; 563:79-93.

56. Slominski A, Zmijewski MA, Pawelek J. L-tyrosine and L-dihydroxyphenylalanine as hormone-like regulators of melanocyte functions. Pigment Cell Melanoma Res. 2012; 25:14-27.

57. Slominski RM, Zmijewski MA, Slominski AT. The role of melanin pigment in melanoma. Exp Dermatol. 2015; 24:258-259.

58. Janjetovic Z, Brozyna AA, Tuckey RC, Kim TK, Nguyen MN, Jozwicki W, Pfeffer SR, Pfeffer LM, Slominski AT. High basal NF-kappaB activity in nonpigmented melanoma cells is associated with an enhanced sensitivity to vitamin D3 derivatives. Br J Cancer. 2011; 105:1874-1884.

59. Slominski A, Tobin DJ, Shibahara S, Wortsman J. Melanin pigmentation in mammalian skin and its hormonal regulation. Physiol Rev. 2004; 84:1155-1228.

60. Brozyna AA, Jozwicki W, Carlson JA, Slominski AT. Melanogenesis affects overall and disease-free survival in patients with stage III and IV melanoma. Hum Pathol. 2013; 44:2071-2074.

61. Brozyna AA, Jozwicki W, Roszkowski K, Filipiak J, Slominski AT. Melanin content in melanoma metastases affects the outcome of radiotherapy. Oncotarget. 2016; 7:17844-17853. http://doi.org/10.18632/oncotarget.7528.

62. Cichorek M, Kozlowska K, Bryl E. The activity of caspases in spontaneous and camptothecin-induced death of melanotic and amelanotic melanoma cell. Cancer Biol Ther. 2007; 6:346-353.

63. Brozyna AA, VanMiddlesworth L, Slominski AT. Inhibition of melanogenesis as a radiation sensitizer for melanoma therapy. Int J Cancer. 2008; 123:1448-1456.

64. Slominski A, Zbytek B, Slominski R. Inhibitors of melanogenesis increase toxicity of cyclophosphamide and lymphocytes against melanoma cells. Int J Cancer. 2009; 124:1470-1477.

65. Balch CM, Gershenwald JE, Soong SJ, Thompson JF, Atkins MB, Byrd DR, Buzaid AC, Cochran AJ, Coit DG, Ding S, Eggermont AM, Flaherty KT, Gimotty PA, et al. Final version of 2009 AJCC melanoma staging and classification. J Clin Oncol. 2009; 27:6199-6206.

66. Kashani-Sabet M, Sagebiel RW, Ferreira CM, Nosrati M, Miller JR 3rd. Tumor vascularity in the prognostic assessment of primary cutaneous melanoma. J Clin Oncol. 2002; 20: 7:1826-1831.

67. Clemente C, Cochran AJ, Elder DE, Levene A, MacKie RM, Mihm MC, Rilke F, Cascinelli N, Fitzpatrick TB, Sober AJ. Histopathologic diagnosis of dysplastic nevi: concordance among pathologists convened by the World Health Organization Melanoma Programme. Hum Pathol. 1991; 22:313-9. 